IZA DP No. 8401

Changes in Labour Market Transitions in Ireland over the Great Recession

Adele Bergin

Elish Kelly

Seamus McGuinness

August 2014 


\title{
Changes in Labour Market Transitions in Ireland over the Great Recession
}

\author{
Adele Bergin \\ Economic and Social Research Institute \\ and Trinity College Dublin \\ Elish Kelly \\ Economic and Social Research Institute \\ and Trinity College Dublin \\ Seamus McGuinness \\ Economic and Social Research Institute, \\ Trinity College Dublin, NILS, Flinders University and IZA

\section{Discussion Paper No. 8401 August 2014} \\ IZA
P.O. Box 7240
53072 Bonn
Germany \\ Phone: $+49-228-3894-0$ \\ Fax: +49-228-3894-180 \\ E-mail: iza@iza.org
}

\begin{abstract}
Any opinions expressed here are those of the author(s) and not those of IZA. Research published in this series may include views on policy, but the institute itself takes no institutional policy positions. The IZA research network is committed to the IZA Guiding Principles of Research Integrity.

The Institute for the Study of Labor (IZA) in Bonn is a local and virtual international research center and a place of communication between science, politics and business. IZA is an independent nonprofit organization supported by Deutsche Post Foundation. The center is associated with the University of Bonn and offers a stimulating research environment through its international network, workshops and conferences, data service, project support, research visits and doctoral program. IZA engages in (i) original and internationally competitive research in all fields of labor economics, (ii) development of policy concepts, and (iii) dissemination of research results and concepts to the interested public.
\end{abstract}

IZA Discussion Papers often represent preliminary work and are circulated to encourage discussion. Citation of such a paper should account for its provisional character. A revised version may be available directly from the author. 
IZA Discussion Paper No. 8401

August 2014

\section{ABSTRACT \\ Changes in Labour Market Transitions in Ireland over the Great Recession}

This paper assesses the impact that the 2009 Great Recession had on individual's transitions to and from unemployment in Ireland. The rate of transition from unemployment to employment declined between 2006 and 2011, while the rate from employment to unemployment increased. The impact of some of the factors identified as contributing to the likelihood of a transition taking place were found to have changed over this period. In particular, young people are much less likely to exit unemployment, but at the same time they have a lower risk of becoming unemployed. Education has become an increasingly important factor in both supporting unemployment exits and reducing the risk of becoming unemployed since the recession. The scarring impact of long-term unemployment appears to have fallen substantially in Ireland post-recession. The results from a decomposition analysis show that compositional changes are largely unimportant in explaining the change in the transition rates between 2006 and 2011.

JEL Classification: J64, J88

Keywords: $\quad$ labour market transitions, Great Recession, longitudinal data, decomposition techniques, Ireland

Corresponding author:

Seamus McGuinness

The Economic and Social Research Institute

Whitaker Square

Sir John Rogerson's Quay

Dublin 2

Ireland

E-mail: Seamus.McGuinness@esri.ie 


\section{Introduction}

While few countries escaped the adverse impact of the Great Recession of 2009, Ireland experienced one of the most severe downturns in the industrialised world. Between 2008 and 2009, the country suffered a cumulative fall in Gross National Product of close to 9 per cent. By 2012 (Q3), real GNP was 8.5 per cent below its 2008 (Q1) level, which is a stark depiction of the rate of contraction experienced within the economy. This collapse in economic activity has had severe knock-on effects on Ireland's labour market. In particular, the unemployment rate increased from 4.6 per cent in 2004 to 15.0 per cent in 2012 , while, as one would expect, the employment rate declined - falling from 65.9 per cent in 2004 to 58.8 per cent in 2012 (see Table 1).

\section{$<$ Insert Table 1 here >}

The collapse in the property sector in Ireland, which was one of the main factors underlining its economic demise, resulted in most job losses occurring in the construction sector, and in particular among males. McGinnity et al. (2014) report that the number of people employed in the construction sector fell by just over 61 per cent between 2007 and 2012 - falling from 266,174 to 103,212 with the sector's share in total employment falling from 12.6 per cent in 2007 to 5.5 per cent in 2012. Apart from Information and Communication, Education, Health and the Arts, all other sectors experienced job losses, but none to the extent of the construction sector.

As the downturn progressed, the profile of unemployed people changed, particularly in terms of their educational composition. In 2006, prior to the recession, over two-thirds of those who were unemployed had a second-level qualification or less, with only a fifth having completed third-level. However, over the course of the recession there has been a striking growth in the number of unemployed individuals with a Post Leaving Cert ${ }^{1}$ (PLC) level qualification (which includes apprenticeships), while the proportion of unemployed females with a graduate qualification increased significantly, from 22.5 per cent in 2006 to 30.8 per cent in 2011 (Kelly, McGuinness and O'Connell, 2012).

Existing literature on the impact of the recession on the Irish labour market has found that it has had a differential impact across age groups, with young people in particular being severely affected. Kelly et al. (2013) report that total employment among those aged 25 and less fell by almost 60 per cent, from 357,000 in Q3 2007 to 148,000 in Q1 2013. There has been a small increase in the number of employed youths since this time-point, with the figure standing at 153,000 in Q1 2014. The corollary of this fall in employment among young

1 This is a post-secondary, mainly vocational, qualification. 
people has been a rapid rise in their unemployment rate, which has grown from 9 per cent in Q3 2007 to almost 30 per cent in Q3 2011, and also a rise in inactivity. Conefrey (2011) found that the majority of young people who exited the labour force after the recession in 2008, and who remained in Ireland, returned to education. However, Kelly et al. (2013) found that the rate of transition to employment of those who became unemployed fell considerably, from 38 per cent in 2006 to 17.4 per cent in 2011. Kelly et al. (2013) results showed that this fall in the transition rate was not due to changes in the composition of unemployed youths but to adjustments in the external economic environment that resulted in changes in the impact of possessing certain individual characteristics. For example, there was a rise in the marginal impact of education and Irish nationality on the probability of a successful transition from unemployment to employment. The number of young people not in employment, education or training i.e., NEETs, has also grown since the recession, increasing from 11.8 per cent in 2006 to 24 per cent in 2011 (Eurostat, 2013). ${ }^{1}$ Similar to unemployed youths, Kelly and McGuinness (2013) found that NEET individuals' transition rate to employment fell over the course of the recession as well - declining from 21.4 per cent in 2006 to 13.6 per cent in 2011.

Research by Barrett and Kelly (2012) shows that the recession has had a differential nationality effect and, in particular, that immigrants have suffered more than natives. They report that the annual rate of job loss was close to 20 per cent for immigrants in 2009 compared to about 7 per cent for Irish-born. In addition, Barrett and Kelly (2012) found that the employment probabilities of immigrants from the accession states that joined the European Union in May 2004 were particularly negatively affected, especially males from these countries.

In the context of the dramatic changes that have taken place in the Irish labour market since the Great Recession of 2009, this paper focuses on identifying the impact that various socioeconomic characteristics (e.g., age, gender, marital status, etc.) and job traits (e.g., employment sector, trade union membership, etc.) have on the relative risk of a person losing their job (i.e., transitioning from employment to unemployment) or finding employment (i.e., transitioning from unemployment to employment) and, in particular, assesses how the impact of such characteristics have changed pre and post the Great Recession. In addition to examining the impact of various socio-economic characteristics on individual's labour market transition patterns, we are also interested in investigating what has driven the change in the unemployment-to-employment and employment-tounemployment transition rates between 2006 and 2011. This analysis is carried out using decomposition techniques.

The remainder of the paper is structured as follows. Section 2 describes the data that is used in the study. Descriptive statistics are presented in Section 3. The methodology and results are outlined in Sections 4, while the main conclusions are presented in Section 5. 


\section{Data}

Newly available longitudinal data from the Quarterly National Household Survey (QNHS), which is Ireland's Labour Force Survey, ${ }^{2}$ is used to conduct the analyses undertaken in this paper. The objective of the QNHS is to provide quarterly labour force estimates of employment, unemployment, etc. The survey is continuous and targets all private households. Each quarter, approximately 26,000 households are sampled. ${ }^{3}$ Households are asked to take part in the survey for five consecutive quarters. In each quarter, one-fifth of the households surveyed are replaced and the QNHS sample involves an overlap of 80 per cent between consecutive quarters and 20 per cent between the same quarters in consecutive years. While participation in the QNHS is voluntary, the response rate is high (approximately 85 per cent). ${ }^{4}$

One of the main benefits of using the QNHS longitudinal data is that it allowed us to follow the labour market transitions of individuals for up to 5 consecutive quarters. In terms of the periods covered in our study, we focused on comparing individuals labour market transitions both pre and post the Great Recession. Quarter 2 (Q2) 2006 was selected as the starting point for our pre-recession analysis, which was during the height of the boom in Ireland; and Q2 2011 marked the starting point for the analysis relating to the post-recession period. Given that we only consider individuals who remain in Ireland over the observation periods, those who migrated to or from Ireland during the time period covered by each panel are excluded from the analysis.

In this paper, we begin by assessing the impact of various socio-economic and employment characteristics on an unemployed person's likelihood of transitioning to employment. We then examine the impact of the same characteristics on an employed person's likelihood of becoming unemployed. Models are estimated for both 2006 and 2011. The characteristics investigated are as follows: gender, age, nationality, marital status, educational attainment, geographic location, sector of employment, previous unemployment duration, trade union membership, employment contract type, job type (i.e., full-time or part-time), firm size and job search methods.

\section{Descriptive Statistics}

Table 2 shows average transition rates over the five waves for 2006 and 2011. In 2006, the pre-crisis period, over 37 per cent of those who were unemployed in the previous quarter transitioned into employment. In 2011, the average unemployment to employment transition rate had fallen by almost 10 percentage points. In 2006, when the economy was 
essentially at full employment, the transition rate from employment to unemployment was under 2 per cent and this rate rose to just under 5 per cent in 2011.

There is an almost linear negative relationship between age and transitioning to unemployment. Apart from the youngest age group (15-19), the employment to unemployment transition rates approximately trebled for each age group in 2011 compared to 2006.

Younger workers have the lowest transition rates from unemployment to employment. The employment transition rates fell for all age groups in 2011, with the largest percentage point falls occurring for those under the age of 35 .

Table 2 reveals that those with higher levels of education are less likely to move to unemployment, and this effect is more marked in 2011. There is a strong positive relationship between education level and transitioning into employment. In 2006, 60 per cent of unemployed graduates moved into employment while the comparable figure for those with less than Leaving Certificate education was only 24 per cent. In 2011, the education gradient persisted although the transition rates had fallen somewhat for each education level.

\section{$<$ Insert Table 2 here $>$}

\section{Methodology and Results}

With respect to assessing the link between measures of labour market status in period $t$ and $t+1$, we employ a random effects logit model. We estimate separate models for two distinct labour market transitions between the two periods - i) transitions from unemployment to employment and ii) transitions from employment to unemployment, with the equations taking the following general form:

$$
\begin{aligned}
& Y_{i t+1}=X_{i t}^{\prime} \beta+\bar{X}_{i}^{\prime} \lambda+\alpha_{i}+u_{i t} \\
& (\mathrm{i}=1, \ldots, \mathrm{N} ; \mathrm{t}=1, \ldots, \mathrm{T})
\end{aligned}
$$

where Xit is a vector of personal and job characteristics; $\alpha i$ are the individual random effects; and uit is an error term, which is assumed to be identically and independently distributed. The models are estimated on two unbalanced panels covering Q2 2006 to Q2 2007 and Q2 2011 to Q2 2012. 
The main weakness with the random effects model proposed here is that it assumes the explanatory variables are uncorrelated with the error term, suggesting that a fixed effects model, where individual-specific effects are captured through the inclusion of a separate intercept for each individual in the data, might be more appropriate. A conditional fixed effects logit model might have been estimated, but comes at a huge cost: ii) the loss of many cases, since these models are conditional on changes in the outcome variable being observed, which is a particular problem when using quarterly panel data and (ii) since most of the explanatory variables will not change over five quarters most of our controls relating to, for example, education, region and industrial sector will drop out of the models. For these reasons, we are forced to adopt the random effects logit model. Nevertheless, as we are interested in changes in the value of observable characteristics over time, and accepting that any bias relating to unobserved heterogeneity is likely to affect both panels in similar ways, we are less concerned with respect to potential correlations with the error term in our current context.

Table 3 shows the results from models estimating the likelihood of transitioning from unemployment to employment in both 2006 and 2011. The odds ratios for each observable characteristic are reported and a number of notable changes in the importance of certain attributes are apparent pre and post recession. In 2006, relative to the comparison case of individual's aged 15 to 19 , older workers were, on average, 4 to 5 times the odds of transitioning into employment, with the effect being relatively constant throughout the age ranges. By 2011, relative to the base case, workers aged 20 to 24 had almost ten times the odds of successfully exiting to employment, while individuals in the older age brackets had between 27 and 45 times the odds of finding a job relative to 15 to 19 year old unemployed individuals. This result highlights the desperate position of youth unemployed and the importance of initiatives, such as the Youth Guarantee, that target job search and education and training assistance towards younger claimants.

Education was important in securing an exit to employment in both periods, but its importance rose substantially between 2006 and 2011, particularly with respect to ThirdLevel qualifications. Prior to the recession, claimants with Third-Level Certificates/Diplomas and Degrees had between 6 and 10 times the odds of finding employment relative to individuals with a primary education or less, which is quite large. However, by 2011 those with a Third-Level Certificate/Diploma qualification were almost 40 times more likely to find a job relative to those with primary or less qualification, while those with a third-Level degree were 126 times more likely to obtain employment. These results suggest that new and replacement labour demand in Ireland post-recession was heavily skewed towards graduates.

In 2006, we observe the well documented scarring effect of previous unemployment durations on unemployment-to-employment labour market transitions. Relative to 
individuals who were unemployed for less than three months, those with durations of between 6 to 12 months or more than 12 months had around two-thirds (0.66) and onethird (0.37), respectively, the odds of moving into employment by the following quarter. By 2011, however, we find that previous unemployment duration had no discernible impact on exits to employment. One possible explanation for the disappearance of the scarring effect is that the magnitude, and indiscriminate nature, of the incidence of both unemployment and long-term unemployment over the period eradicated the value of durations as a quality signal to employers. Alternatively, the rapid rise in the population of long-term unemployed of individuals with high levels of labour market attachment, may have led to a structural behavioural shift in the intensity of job-search among long-term claimants which will also have dampened the scarring effect.

The QNHS contains a number of variables that capture the extent to which an unemployed individual is awaiting a response on a job application and the nature of any job-search activity undertaken in the previous quarter. In 2006, individuals awaiting the results from a public sector competition or an aptitude test had between 30 and 40 times the odds of exiting to employment by the following quarter relative to unemployed individuals who were not awaiting a response to one of these two job application activities. In 2006 none of the job search variables had any significant impact on exits from unemployment, with the exception of contact with a public employment office: such individuals had just over one times the odds of not finding a job relative to unemployed individuals that did not use this type of job search activity. ${ }^{5}$ Differences in job search activity became somewhat more important in the later period, with individuals who had interacted with a private employment agency having one and a half times the odds of entering employment by the following quarter relative to those who did not engage with a private recruitment group in 2011. The same result emerged for those waiting the results from a public sector employment competition in 2011. On the other hand, unemployed individuals who had engaged with a public employment office, sought work through family or friends or by searching newspaper advertisements all had lower odds of finding a job within three months relative to unemployed people that did not utilise these job search methods. ${ }^{6}$

With respect to gender, males had almost twice the odds of exiting to employment in 2006 relative to females. However, by 2011 the situation had reversed with males having around two-thirds (0.61) the odds of moving from unemployment to employment than females. In both time periods examined in this study, Irish national that were unemployed were more likely to transition out of unemployment than immigrants, with the scale of the advantage rising in 2011. Neither pre or post the Great Recession did previous industrial sector of employment have any importance in explaining transitions into employment. Married individuals were more likely to successfully exit from unemployment in both periods. Finally, while unemployment-to-employment transition rates were generally lower in most regions relative to Dublin in 2006, the majority of such regional effects had dissipated by the later period. 


\section{$<$ Insert Table 3 here $>$}

Table 4 shows the impact of characteristics on the risk of unemployment in both 2006 and 2011. Again, we report the odds ratios associated with a range of attributes for both time periods. It is important to note that we cannot distinguish the extent to which transitions from employment-to-unemployment were as a consequence of involuntary or voluntary separations. Nevertheless, it is reasonable to assume that the majority of separations were involuntary in nature, particularly in 2011 when the Irish economy was still experiencing substantial difficulties. As was the case with unemployment-to-employment transitions, we observe substantial change in the impacts of age and gender over the period. In 2006, relative to 15 to 19 year olds, employees aged 20 to 34 had a higher risk of unemployment, as measured by higher odds ratios, while those aged 35 and over had lower odds of becoming unemployed - with the risk falling with age. In 2011, employees aged between 20 and 54 had between 1.6 and five times the odds of becoming unemployed relative to the younger cohort. Only workers aged 55 and over had a lower risk of unemployment in 2011 compared to those aged 15 to 19 . A potential explanation for this result is that firms became more sensitive to the price of labour post-recession, implying that the youngest workers, who also tend to be the least expensive, had the lowest risk of a redundancy arising from any cost rationalisation process. Nevertheless, it must be borne in mind that younger workers, due to their relative lack of experience are also likely to be less productive, suggesting that any substitution for more experienced labour is likely to be restricted to relatively unskilled occupations. Thus, while 15 to 19 year olds are at the greatest risk of sustained unemployment, they appear to have a relatively low risk of job loss.

With respect to education, we observe a general linear relationship in both periods, with the risk of unemployment declining with higher levels of educational attainment. Relative to 2006, third-level qualifications are of greater importance in deterring unemployment in 2011, which is again consistent with a change in the composition of labour demand in favour of educated workers. Furthermore, by 2011, the Post Leaving Cert (PLC) level qualification, which are typically vocational in nature, no longer afforded workers any advantage relative to those with primary or less education. In 2006, males had approximately 1.5 times the odds of transitioning to unemployment relative to females. However, by 2011 males had over three times the odds of transitioning into unemployment compared to females. In the earlier period, Irish workers and immigrants had a similar risk of becoming unemployed, but by 2011 Irish natives had approximately half the odds of moving into unemployment relative to immigrants.

In 2006, relative to Manufacturing, the risk of moving into unemployment was higher for workers in Accommodation and Food Services and Administrative and Support Services, and lower for those in the Agriculture, Public Administration, ProfessionalFinancial and 
Information and Communication sectors. By 2011, only workers in the Public Administration sector had a lower likelihood of becoming unemployed. In both 2006 and 2011, full-time workers, and those who were members of trade-unions, had lower odds of unemployment, with the impact relatively constant over time. Finally, with respect to region, relative to Dublin the risk of unemployment was lower in a number of areas in 2006 (e.g., Mid-East and Midlands). However, by 2011 employees located in areas other than Dublin had higher odds of becoming unemployed. This result suggests a greater concentration of economic activity in the capital post-recession.

\section{$<$ Insert Table 4 here $>$}

The random effects logit models gave us a sense of the extent to which the value of certain attributes changed pre and post recession with respect to transitioning from, or falling into, unemployment. It is not clear, however, the extent to which variations in the transition rate over time or being driven by (i) changes in the value of observable characteristics, (ii) changes in the composition of the populations in employment and unemployment, or (iii) unobservables that may relate to either individuals or changes in the external environment. In order gain further insights, we estimate a non-linear decomposition, on the pooled waves, of the change in transition rates from 2006 to 2011 and the results are shown in Table $5 .^{7}$

The first observation to note is that endowment effects explained very little of the overall change in either transition rate examined, suggesting that changes in the composition of the respective populations over the period mattered little. While the structure of employment will tend to change slowly over time, the lack of an endowment effect on the transition from unemployment-to-employment is somewhat surprising given the well documented rapid growth in the proportions of unemployed claimants with higher levels of education since the onset of the recession.

Dealing firstly with the transitions from unemployment-to-employment, the vast majority of the change in the transition rate can be attributed to changes in the constant coefficient, which will incorporate largely unobserved external factors. Nevertheless, some changes in the value of certain observable characteristics had important impacts on the changing rate of transition. The decline in the impact of being male is the most important single coefficient effect, which resulted in a 6 percentage point reduction in the transition rate from unemployment-to-employment between 2006 and $2011 .{ }^{8}$ It is not clear what the gender coefficient effect is picking up, given that the models account for claimants previous industrial sector. However, it is not necessarily the case that the control for previous sector of employment will reflect the degree to which the human capital of claimants meets the requirements of current labour demand. Given this, the results would suggest that between 2006 and 2011 the demand for labour dramatically switched towards industries and 
occupations where females were more heavily represented, with little evidence that claimants previously employed in particular sectors of employment heavily affected by the economic downturn where at any particular disadvantage in accessing emerging opportunities. In support of this view, McGinnity et al., (2014) show that the Health and Social Work sector, which is heavily female dominated, exhibited the largest absolute level of sectoral employment growth ${ }^{9}$ in Ireland over the 2007 to 2012 period. $^{10}$

The rise in the coefficients for older unemployed individuals, which presumably proxies an increase in the value of labour market experience, exerted a positive influence on the change in the transition rate. The very substantial reduction the scarring impact of long-term unemployment durations also tended to increase transition rates over the period. The elimination of the decline in the relative return to the vocationally orientated PLC qualification had a depressing affect on the transition rate and, it is again likely that the fall in the return to this qualification is correlated with the lack of demand in vocationally orientated sectors such as Construction, Manufacturing and Wholesale and Retail.

With respect to the rise in the rate of transitions to unemployment, ${ }^{11}$ the increase in the relative exposure of males and older workers were the largest single coefficient effects. In this instance, the age effect may well reflect a rise in the price sensitivity of employers to labour costs post recession.

\section{$<$ Insert Table 5 here $>$}

\section{Summary and Conclusions}

This paper assesses the impact of the Irish recession on transitions to and from unemployment. We find, not surprisingly, that the rate of transition from unemployment to employment declined over the period, while the transition rate from employment to unemployment increased.

In terms of the factors contributing to the likelihood of a transition taking place, some important changes appear to have occurred over the 2006 to 2011 period. The results show that young people are much less likely to exit unemployment, while simultaneously having a lower risk of becoming unemployed. Education has become an increasingly important factor post recession in both securing an exit from unemployment and preventing transitions to unemployment, with the impact most pronounced for the transition from unemploymentto-employment. We find that the scarring effect of long-term unemployment has fallen substantially post-recession, suggesting that (a) the rapid and indiscriminate rise in the incidence of long-term durations has eradicated the signalling value of the attribute, or (b) structural shifts in the population of long-term claimants has led to a rise in the job-search 
intensity causing a decline in the relationship between unemployment durations and exits to employment.

Despite the rapid changes in the structure of the unemployed population, results from a decomposition analysis show that compositional changes are largely unimportant in explaining the fall in the transition rate from unemployment to employment between 2006 and 2011. While most of the change is, not surprisingly, attributable to unobserved changes in the external environment, variations in the value of certain attributes also explained some of the movement in transition rates. In particular, we find that the fall in the return of being male over time contributed to a decline in the transition rate from unemployment to employment, with the gender effect indicating that labour demand was more heavily skewed towards female dominated sectors over the 2006 to 2011 period. The decline in the scarring effect of long-term unemployment and the relative rise in the return to labour market experience, proxied by age, exerted a positive influence on the transition rate to employment over the period.

From a policy perspective the results emphasise the importance of higher level credentials in terms of preventing transitions to unemployment and exiting unemployment. The research is suggestive of a rise in demand for graduate labour over time, which would be supportive of further expansion of higher-education provision. The study also identifies that labour demand is evolving in an uneven pattern with respect to both male and female dominated industries. Over the period in question, employment growth appears to have been particularly skewed towards female dominated sectors, which has resulted in a substantial lowering in the likelihood that males will exit the Live Register ${ }^{12}$ in any three-month period.

With respect to labour market activation, the research highlights the drastic situation faced by unemployed youth. This would emphasise the importance of implementing the Youth Guarantee, which is still only at the pilot stage in Ireland.

Finally, the apparent reduction of the scarring effect associated with long-term unemployment suggests that activation policy need not be so heavily focused around durations, but instead should attempt to ensure that the claimants are equipped with the right skills and provided with the appropriate advice and training that would enable them to re-enter employment irrespective of their length of time spent on the Live Register.

\section{Competing Interests:}

The authors declare that they have no competing interests, either financial or non-financial. 


\section{Authors' Contributions:}

All listed authors - $A B, E K$ and $S M c G$, were involved in formulating the objectives addressed in the paper, the data preparation work, the econometric modelling, the write-up of the results and, finally, reading and approving the paper for submission to the journal.

\section{Acknowledgements:}

We would like to thank the Central Statistics Office (CSO) for making the Quarterly National Household Survey (QNHS) data available to us and, in particular, Brian Ring (CSO) for his assistance with data queries. 
1 Eurostat, March 2013: http://appsso.eurostat.ec.europa.eu/nui/setupModifyTableLayout.do

2 The QNHS is carried out by the Central Statistics Office (CSO), Ireland's national statistical collection organisation.

3 The CSO introduced a new sample in Quarter 42012 as a result of the 2011 Census of Population. The new sample is being introduced on an incremental basis across each quarter from Quarter 42012 to Quarter 42013. Thus, the new sample will not be fully effective until Quarter 42013.

4 Information provided by the CSO.

5 This finding is consistent with the work of McGuinness et al., (2011) who report that the activation system in force at the time (2006), the National Employment Action Plan (NEAP), actively reduced exits from the Live Register to employment.

6 With respect to the public employment office, while the NEAP was in the process of being replaced in 2011, the scale of the unemployment problem at that time meant that existing resources were severely stretched in their ability to deal with the unemployment crisis that existed in the country at that time.

7 We estimate the following non-linear Oaxaca decomposition: $\overline{T_{11}}-\overline{T_{06}}=\left(\overline{X_{11}}-\overline{X_{06}}\right) \widehat{\beta_{11}}+\left(\widehat{\beta_{11}}\right.$ $\left.\widehat{\beta_{106}}\right) \overline{X_{06}}+\left(\widehat{\alpha_{11}}-\widehat{\alpha_{06}}\right)$ The term on the left-hand-side, $\overline{T_{11}}-\overline{T_{06}}$, captures the change in the transition rate between 2006 and 2011. The first term on the right-hand-side describes the endowment effect, the second term captures the coefficient effect, while the final term denotes the factors that we cannot control for in our model.

8 See Appendix Table A1.

9 Sectoral employment increased by 23,585 (10.6 per cent).

10 Over the period, total employment fell by 303,091 (14.1 per cent).

11 See Appendix Table A2.

12 Ireland's national register of all individuals in receipt of unemployment benefits. 


\section{References:}

Barrett, A. and E. Kelly. (2012) 'The Impact of Ireland's Recession on the Labour Market Outcomes of its Immigrants', European Journal of Population, Vol. 28, No. 1.

Central Statistics Office. (2012). Live Register: December 2011. Cork: Central Statistics Office.

Central Statistics Office. (2013a). Live Register: February 2013. Cork: Central Statistics Office

Central Statistics Office. (2013b). Quarterly National Household Survey: Quarter 42012. Cork: Central Statistics Office.

Conefrey, T. (2011). "Unemployment and Labour Force Participation During the Recession", Economic Letter Series from Central Bank of Ireland, Vol. 2011, No. 4.

Kelly, E., S. McGuinness and P.J. O'Connell (2012). Submission to the Joint Committee on Jobs, Social Protection and Education on Unemployment and Youth Unemployment.

Kelly, E. and S. McGuinness (2013). "The Impact of the Recession on the Structure and Labour Market Success of NEET Youth in Ireland", Intereconomics, 48 (4): 196-235.

Kelly, E., S. McGuinness, P.J. O’Connell, D. Haugh and A. Pandiella González (2013), "Transitions In and Out of Unemployment Among Young People in the Irish Recession", ESRI Working Paper 466.

McGinnity, F., H. Russell, D. Watson, G. Kingston and E. Kelly (2014). Winners and Losers? The Equality Impact of the Great Recession in Ireland. Dublin: The Equality Authority and the Economic and Social Research Institute.

McGuinness, S., P.J. O'Connell, E. Kelly and J.R. Walsh. (2011). Activation in Ireland: An Evaluation of the National Employment Action Plan. ESRI Research Series No. 20. Dublin: Economic and Social Research Institute. 
Table 1: Irish Labour Force Statistics: 2004 to 2014

\begin{tabular}{|c|c|c|c|c|c|c|c|c|c|c|c|}
\hline & $\begin{array}{l}2004 \\
\text { (Q2) }\end{array}$ & $\begin{array}{l}2005 \\
\text { (Q2) }\end{array}$ & $\begin{array}{l}2006 \\
\text { (Q2) }\end{array}$ & $\begin{array}{l}2007 \\
\text { (Q2) }\end{array}$ & $\begin{array}{l}2008 \\
\text { (Q2) }\end{array}$ & $\begin{array}{l}2009 \\
\text { (Q2) }\end{array}$ & $\begin{array}{l}2010 \\
(Q 2)\end{array}$ & $\begin{array}{l}2011 \\
\text { (Q2) }\end{array}$ & $\begin{array}{l}2012 \\
\text { (Q2) }\end{array}$ & $\begin{array}{l}2013 \\
\text { (Q2) }\end{array}$ & $\begin{array}{l}2014 \\
\text { (Q1) }\end{array}$ \\
\hline Unemployment rate \% & 4.6 & 4.7 & 4.6 & 4.8 & 5.7 & 12.2 & 13.9 & 14.6 & 15.0 & 13.9 & 12.0 \\
\hline Participation rate \% & 60.5 & 62.1 & 63.2 & 64.1 & 63.7 & 62.5 & 61.1 & 60.5 & 60.1 & 60.5 & 59.7 \\
\hline $\begin{array}{l}\text { Employment rate \% } \\
\text { (persons aged } 15-64 \text { ) }\end{array}$ & 65.9 & 67.5 & 68.5 & 69.1 & 67.9 & 62.2 & 60.0 & 59.2 & 58.8 & 60.2 & 60.8 \\
\hline
\end{tabular}

Source: Quarterly National Household Survey, Central Statistics Office. ${ }^{12}$

Table 2: Transition Rates

\begin{tabular}{|c|c|c|}
\hline & 2006 & 2011 \\
\hline \multicolumn{3}{|l|}{ Overall: } \\
\hline Employment to Unemployment & $1.8 \%$ & $4.9 \%$ \\
\hline Unemployment to Employment & $37.3 \%$ & $27.8 \%$ \\
\hline \multicolumn{3}{|l|}{ By Age Group: } \\
\hline \multicolumn{3}{|l|}{ Employment to Unemployment: } \\
\hline $15-19$ & $3.3 \%$ & $6.3 \%$ \\
\hline $20-24$ & $3.4 \%$ & $9.7 \%$ \\
\hline $25-34$ & $2.0 \%$ & $6.1 \%$ \\
\hline $35-44$ & $1.4 \%$ & $4.3 \%$ \\
\hline $45-54$ & $1.2 \%$ & $3.6 \%$ \\
\hline 55 plus & $0.8 \%$ & $2.6 \%$ \\
\hline \multicolumn{3}{|l|}{ Unemployment to Employment: } \\
\hline $15-19$ & $19.5 \%$ & $8.5 \%$ \\
\hline $20-24$ & $43.4 \%$ & $23.1 \%$ \\
\hline $25-34$ & $43.3 \%$ & $30.8 \%$ \\
\hline $35-44$ & $38.7 \%$ & $31.4 \%$ \\
\hline $45-54$ & $38.8 \%$ & $31.4 \%$ \\
\hline 55 plus & $33.5 \%$ & $26.9 \%$ \\
\hline \multicolumn{3}{|l|}{ By Education Level: } \\
\hline \multicolumn{3}{|l|}{ Employment to Unemployment: } \\
\hline Below Leaving Certificate & $2.1 \%$ & $6.0 \%$ \\
\hline Leaving Cert & $1.9 \%$ & $5.7 \%$ \\
\hline PLC & $1.6 \%$ & $6.8 \%$ \\
\hline Third Level non-degree & $1.5 \%$ & $3.6 \%$ \\
\hline Third Level degree & $1.2 \%$ & $2.9 \%$ \\
\hline \multicolumn{3}{|l|}{ Unemployment to Employment: } \\
\hline Below Leaving Certificate & $24.3 \%$ & $15.7 \%$ \\
\hline Leaving Cert & $43.0 \%$ & $27.5 \%$ \\
\hline PLC & $46.9 \%$ & $27.2 \%$ \\
\hline Third Level non-degree & $49.1 \%$ & $40.7 \%$ \\
\hline Third Level degree & $59.8 \%$ & $50.0 \%$ \\
\hline
\end{tabular}

Note: Derived from the QNHS micro-data. The base for the employed to unemployed transition rates is employed in the previous quarter and the base for the unemployed to employed transition rates is unemployed in the previous quarter. 
Table 3: Odds Ratios from Random Effects Logit Estimations of Transitions from Unemployment to Employment

\begin{tabular}{|c|c|c|c|c|}
\hline & \multicolumn{2}{|c|}{2006} & \multicolumn{2}{|c|}{2011} \\
\hline & Odds Ratio & Standard Error & Odds Ratios & Standard Error \\
\hline Male & $1.902 * * *$ & 0.195 & $0.611^{* * *}$ & 0.069 \\
\hline Age $20-24$ & $5.063 * * *$ & 0.996 & $9.888 * * *$ & 3.226 \\
\hline Age 25-34 & $5.138^{* * *}$ & 1.013 & $33.055^{* * *}$ & 11.267 \\
\hline Age $35-44$ & $4.559 * * *$ & 0.936 & $37.615^{* * *}$ & 13.202 \\
\hline Age $45-54$ & $5.541 * * *$ & 1.195 & $44.614 * * *$ & 16.041 \\
\hline Age 55+ & $3.821 * * *$ & 0.855 & $26.761 * * *$ & 9.792 \\
\hline Leaving Certificate & $4.445^{* * *}$ & 0.622 & $10.605^{* * *}$ & 1.726 \\
\hline Post Leaving Certificate & $4.761 * * *$ & 0.913 & $6.225^{* * *}$ & 1.099 \\
\hline Third Level: non degree & $5.909 * * *$ & 1.211 & $39.703^{* * *}$ & 9.365 \\
\hline Third level: degree & $10.097 * * *$ & 2.059 & $125.744^{* * *}$ & 30.770 \\
\hline Irish & $1.652 * * *$ & 0.143 & $2.857 * * *$ & 0.485 \\
\hline Married & $1.245^{*}$ & 0.146 & $2.581 * * *$ & 0.336 \\
\hline Border & $0.628 * * *$ & 0.100 & $0.660 *$ & 0.151 \\
\hline Mid-East & 0.937 & 0.179 & 0.966 & 0.211 \\
\hline Midlands & 0.703 & 0.155 & 1.092 & 0.264 \\
\hline Mid-West & $0.501 * * *$ & 0.089 & 1.009 & 0.210 \\
\hline South-East & $0.762^{*}$ & 0.125 & 0.728 & 0.142 \\
\hline South-West & $0.705^{* *}$ & 0.108 & 1.228 & 0.229 \\
\hline West & $0.698^{*}$ & 0.133 & 0.962 & 0.200 \\
\hline Prev. unemployed for 3-6 months & 0.876 & 0.111 & 1.217 & 0.206 \\
\hline Prev. unemployed for $6-12$ months & $0.658 * * *$ & 0.084 & 1.145 & 0.186 \\
\hline Prev. unemployed for $12+$ months & $0.368^{* * *}$ & 0.043 & 0.908 & 0.125 \\
\hline Prev. sector: Agriculture & 1.402 & 0.576 & 1.709 & 0.813 \\
\hline Prev. sector: Construction & 0.967 & 0.165 & 1.234 & 0.225 \\
\hline Prev. sector: Wholesale and retail & 1.031 & 0.182 & $1.435^{*}$ & 0.298 \\
\hline Prev. sector: Transport and storage & 0.862 & 0.255 & 1.023 & 0.327 \\
\hline Prev. sector: Accommodation and food service activities & 0.825 & 0.173 & 1.121 & 0.283 \\
\hline Prev. sector: Information and communication & 0.731 & 0.239 & 0.895 & 0.361 \\
\hline Prev. sector: Financial, insurance and real estate activities & 0.797 & 0.286 & 0.790 & 0.358 \\
\hline Prev. sector: Professional, scientific and technical activities & 0.694 & 0.250 & 0.817 & 0.268 \\
\hline Prev. sector: Administrative and support service activities & 0.990 & 0.237 & 1.248 & 0.372 \\
\hline Prev. sector: Public Admin. And defence & 0.703 & 0.315 & 0.581 & 0.295 \\
\hline Prev. sector: Education & 1.387 & 0.410 & 1.536 & 0.554 \\
\hline Prev. sector: Health & 0.901 & 0.228 & 1.093 & 0.326 \\
\hline Prev. sector: Other & 1.247 & 0.312 & 1.081 & 0.316 \\
\hline Prev. sector: No sector info & 0.866 & 0.138 & $1.426^{*}$ & 0.283 \\
\hline Prev. job search: Contacted Public Employment Office & $0.819 *$ & 0.090 & $0.656 * * *$ & 0.073 \\
\hline Prev. job search: Contacted Private Employment Agency & 1.075 & 0.114 & $1.554 * * *$ & 0.176 \\
\hline Prev. job search: Applied Directly to Employers & 0.972 & 0.116 & 1.164 & 0.154 \\
\hline Prev. job search: Asked Friends/Relatives/Trade Unions & 0.846 & 0.103 & $0.643^{* * *}$ & 0.107 \\
\hline Prev. job search: Studied Ads in Newspapers & 1.009 & 0.165 & $0.593 * * *$ & 0.115 \\
\hline Prev. job search: Inserted/Answered Ads in Newspapers & 0.991 & 0.105 & 0.977 & 0.108 \\
\hline \multicolumn{5}{|l|}{ Prev. job search: Looked for Permits, licences or financial } \\
\hline Prev. job search: Looked for land, premises or equipment & 1.317 & 0.885 & 0.987 & 1.073 \\
\hline \multicolumn{5}{|l|}{ Pending Job Decisions: Waiting for call from Public } \\
\hline Employment Office & 0.866 & 0.098 & 1.021 & 0.126 \\
\hline \multicolumn{5}{|l|}{ Pending Job Decisions: Waiting for Public Sector Competition } \\
\hline Results & $1.306^{* * *}$ & 0.136 & $1.540^{* * *}$ & 0.190 \\
\hline Pending Job Decisions: Took a test, interview or exam & $1.396 * * *$ & 0.146 & 1.051 & 0.131 \\
\hline \multicolumn{5}{|l|}{ Pending Job Decisions: Waiting for results from Job } \\
\hline Application & 0.956 & 0.210 & 0.874 & 0.288 \\
\hline Constant & $0.052^{* * *}$ & 0.017 & $0.000^{* * *}$ & 0.000 \\
\hline Number of Obs. & \multicolumn{2}{|c|}{8,299} & \multicolumn{2}{|c|}{18,488} \\
\hline Number of People & \multicolumn{2}{|c|}{6,653} & \multicolumn{2}{|c|}{13,776} \\
\hline Log Likelihood & \multicolumn{2}{|c|}{-4820.0517} & \multicolumn{2}{|c|}{-9450.0625} \\
\hline Prob>chi2 & \multicolumn{2}{|c|}{0.0000} & \multicolumn{2}{|c|}{0.0000} \\
\hline
\end{tabular}

Note: Dependent variable is transitioned from unemployment to employment. Omitted categories are: age 15-19, below Leaving Certificate education, Dublin, previously unemployed for less than three months and Industry. 
Table 4: Odds Ratios from Random Effects Logit Estimations of Transitions from Employment to Unemployment

\begin{tabular}{|c|c|c|c|c|}
\hline & \multicolumn{2}{|c|}{2006} & \multicolumn{2}{|c|}{2011} \\
\hline & Odds Ratio & $\begin{array}{c}\text { Standard } \\
\text { Error }\end{array}$ & Odds Ratio & $\begin{array}{c}\text { Standard } \\
\text { Error }\end{array}$ \\
\hline Male & $1.448 * * *$ & 0.101 & $3.178 * * *$ & 0.186 \\
\hline Age $20-24$ & $1.861 * * *$ & 0.237 & $5.388 * * *$ & 0.712 \\
\hline Age $25-34$ & 1.028 & 0.129 & $3.466 * * *$ & 0.427 \\
\hline Age 35-44 & $0.756^{* *}$ & 0.102 & $2.407 * * *$ & 0.305 \\
\hline Age 45-54 & $0.659 * * *$ & 0.092 & $1.604^{* * *}$ & 0.209 \\
\hline Age 55+ & $0.271 * * *$ & 0.045 & $0.745^{* *}$ & 0.107 \\
\hline Leaving Certificate & $0.613 * * *$ & 0.055 & $0.638 * * *$ & 0.050 \\
\hline Post Leaving Certificate & $0.640 * * *$ & 0.080 & 1.134 & 0.102 \\
\hline Third Level: non degree & $0.589 * * *$ & 0.076 & $0.377^{* * *}$ & 0.038 \\
\hline Third level: degree & $0.381 * * *$ & 0.044 & $0.220 * * *$ & 0.021 \\
\hline Irish & 1.038 & 0.060 & $0.552 * * *$ & 0.044 \\
\hline Married & $0.351 * * *$ & 0.031 & $0.381 * * *$ & 0.025 \\
\hline Border & 1.002 & 0.118 & 1.202 & 0.134 \\
\hline Mid-East & $0.558 * * *$ & 0.074 & $1.313 * * *$ & 0.132 \\
\hline Midlands & $0.569 * * *$ & 0.091 & $1.897^{* * *}$ & 0.228 \\
\hline Mid-West & 0.933 & 0.120 & $1.901 * * *$ & 0.190 \\
\hline South-East & 0.851 & 0.102 & $1.773 * * *$ & 0.175 \\
\hline South-West & $0.735^{* * *}$ & 0.079 & 1.141 & 0.101 \\
\hline West & 0.801 & 0.110 & $1.981^{* * *}$ & 0.199 \\
\hline Prev. sector: Agriculture & $0.432 * * *$ & 0.087 & $0.520 * * *$ & 0.082 \\
\hline Prev. sector: Construction & 1.197 & 0.140 & 1.061 & 0.123 \\
\hline Prev. sector: Wholesale and retail & 0.904 & 0.104 & 0.940 & 0.087 \\
\hline Prev. sector: Transport and storage & 0.894 & 0.150 & 0.947 & 0.125 \\
\hline Prev. sector: Accommodation and food service activities & $1.424 * *$ & 0.200 & 0.940 & 0.108 \\
\hline Prev. sector: Information and communication & $0.662 * *$ & 0.134 & 1.236 & 0.175 \\
\hline Prev. sector: Financial, insurance and real estate activities & $0.671 * *$ & 0.120 & 0.807 & 0.115 \\
\hline Prev. sector: Professional, scientific and technical activities & $0.542 * * *$ & 0.099 & 0.923 & 0.125 \\
\hline Prev. sector: Administrative and support service activities & $1.509 * *$ & 0.252 & 1.105 & 0.158 \\
\hline Prev. sector: Public Admin. And defence & $0.553 * * *$ & 0.104 & $0.724 * *$ & 0.104 \\
\hline Prev. sector: Education & 0.885 & 0.139 & 0.983 & 0.120 \\
\hline Prev. sector: Health & 0.975 & 0.125 & 1.117 & 0.110 \\
\hline Prev. sector: Other & 1.123 & 0.179 & 0.895 & 0.117 \\
\hline Prev. sector: No sector info & 0.715 & 0.411 & 0.415 & 0.291 \\
\hline Prev. Permanent Contract & 1.100 & 0.085 & 1.101 & 0.068 \\
\hline Prev. Full-Time & $0.882^{*}$ & 0.057 & $0.683 * * *$ & 0.035 \\
\hline Prev. Trade Union Member & $0.812^{* *}$ & 0.067 & $0.845^{* *}$ & 0.058 \\
\hline Prev. Firm Size 11-19 & 1.088 & 0.112 & 1.007 & 0.089 \\
\hline Prev. Firm Size 20-49 & 0.917 & 0.092 & 0.970 & 0.079 \\
\hline Prev. Firm Size 50-99 & 1.103 & 0.126 & 0.865 & 0.083 \\
\hline Prev. Firm Size 100-500 & 1.018 & 0.102 & 0.915 & 0.077 \\
\hline Prev. Firm Size 500+ & 1.081 & 0.151 & $0.823^{*}$ & 0.083 \\
\hline Constant & $0.001 * * *$ & 0.000 & $0.004^{* * *}$ & 0.001 \\
\hline Number of Obs. & \multicolumn{2}{|c|}{178,325} & \multicolumn{2}{|c|}{104,879} \\
\hline Number of People & \multicolumn{2}{|c|}{91,815} & \multicolumn{2}{|c|}{57,862} \\
\hline Log Likelihood & \multicolumn{2}{|c|}{-14706.688} & \multicolumn{2}{|c|}{-18397.634} \\
\hline Prob> chi2 & \multicolumn{2}{|c|}{0.0000} & \multicolumn{2}{|c|}{0.0000} \\
\hline
\end{tabular}

Note: Dependent variable is transitioned from employment to unemployment. Omitted categories are: age 15-

19, below Leaving Certificate education, Dublin, Industry and firm size 1-10 employees. 
Table 5: Decomposition Results for Changes in Transition Rates

\begin{tabular}{lcc}
\hline & Employment to Unemployment & Unemployment to Employment \\
\hline Overall Difference & 0.0311 & -0.0921 \\
Endowment Effect & -0.0103 & 0.0277 \\
$\begin{array}{l}\text { Coefficient Effect: } \\
\text { Of which: }\end{array}$ & 0.0325 & -0.1052 \\
$\quad \begin{array}{l}\text { Observables } \\
\text { Constant }\end{array}$ & 0.0105 & 0.0358 \\
& 0.0220 & -0.1410 \\
Interaction Effect & 0.0089 & -0.0146 \\
\hline
\end{tabular}

Note: The decomposition is one for binary dependent variables proposed by Yun (2004). The analysis uses pooled data for 2006 and 2011 and 2006 is the base year in both decompositions. 
Appendix Table A1: $\quad$ Oaxaca Individual Coefficient Effects for the Change in the Unemployment to Employment Transition Rate between 2006 and 2011

\begin{tabular}{|c|c|c|}
\hline & Coefficient & Standard Error \\
\hline Male & $-0.060 * * *$ & $(0.007)$ \\
\hline Age $20-24$ & -0.004 & $(0.004)$ \\
\hline Age $25-34$ & $0.012^{*}$ & $(0.007)$ \\
\hline Age $35-44$ & $0.014^{* *}$ & $(0.006)$ \\
\hline Age 45-54 & $0.011^{* *}$ & $(0.005)$ \\
\hline Age 55+ & $0.008 * *$ & $(0.003)$ \\
\hline Leaving Certificate & -0.004 & $(0.004)$ \\
\hline Post Leaving Certificate & $-0.008 * *$ & $(0.003)$ \\
\hline Third Level: non degree & 0.004 & $(0.002)$ \\
\hline Third level: degree & $0.006^{* *}$ & $(0.003)$ \\
\hline Irish & -0.019 & $(0.012)$ \\
\hline Married & $0.011^{* *}$ & $(0.006)$ \\
\hline Border & 0.002 & $(0.002)$ \\
\hline Mid-East & 0.001 & $(0.002)$ \\
\hline Midlands & 0.002 & $(0.002)$ \\
\hline Mid-West & $0.008 * * *$ & $(0.003)$ \\
\hline South-East & 0.001 & $(0.003)$ \\
\hline South-West & $0.008^{* *}$ & $(0.003)$ \\
\hline West & 0.003 & $(0.003)$ \\
\hline Prev. unemployed for 3-6 months & $0.003^{*}$ & $(0.002)$ \\
\hline Prev. unemployed for 6-12 months & $0.006 * *$ & $(0.003)$ \\
\hline Prev. unemployed for $12+$ months & $0.051 * * *$ & (0.009) \\
\hline Prev. sector: Agriculture & 0.000 & $(0.001)$ \\
\hline Prev. sector: Construction & 0.001 & $(0.005)$ \\
\hline Prev. sector: Wholesale and retail & 0.001 & $(0.003)$ \\
\hline Prev. sector: Transport and storage & 0.001 & $(0.001)$ \\
\hline Prev. sector: Accommodation and food service activities & 0.002 & $(0.002)$ \\
\hline Prev. sector: Information and communication & 0.000 & $(0.001)$ \\
\hline Prev. sector: Financial, insurance and real estate activities & 0.000 & $(0.001)$ \\
\hline Prev. sector: Professional, scientific and technical activities & 0.000 & $(0.001)$ \\
\hline Prev. sector: Administrative and support service activities & 0.000 & $(0.001)$ \\
\hline Prev. sector: Public Admin. And defence & 0.000 & $(0.001)$ \\
\hline Prev. sector: Education & -0.001 & $(0.001)$ \\
\hline Prev. sector: Health & 0.000 & $(0.001)$ \\
\hline Prev. sector: Other & -0.001 & $(0.001)$ \\
\hline Prev. sector: No sector info & 0.005 & $(0.004)$ \\
\hline Prev. job search: Contacted Public Employment Office & -0.006 & (0.008) \\
\hline Prev. job search: Contacted Private Employment Agency & 0.005 & $(0.004)$ \\
\hline Prev. job search: Applied Directly to Employers & 0.014 & $(0.013)$ \\
\hline Prev. job search: Asked Friends/Relatives/Trade Unions & -0.008 & $(0.016)$ \\
\hline Prev. job search: Studied Ads in Newspapers & -0.030 & $(0.021)$ \\
\hline Prev. job search: Inserted/Answered Ads in Newspapers & -0.002 & $(0.004)$ \\
\hline Pending Job Decisions: Waiting for call from Public Employment Office & 0.004 & $(0.004)$ \\
\hline Pending Job Decisions: Waiting for results from Job Application & 0.000 & $(0.001)$ \\
\hline Prev. job search: Looked for Permits, licences or financial resources & 0.000 & $(0.000)$ \\
\hline Prev. job search: Looked for land, premises or equipment & 0.000 & $(0.000)$ \\
\hline Pending Job Decisions: Waiting for Public Sector Competition Results & 0.002 & $(0.003)$ \\
\hline Pending Job Decisions: Took a test, interview or exam & $-0.007 * *$ & $(0.003)$ \\
\hline Constant & $-0.141 * * *$ & $(0.040)$ \\
\hline
\end{tabular}


Appendix Table A2: Oaxaca Individual Coefficient Effects for the Change in the Employment to Unemployment Transition Rate between 2006 and 2011

\begin{tabular}{|c|c|c|}
\hline & Coefficient & Standard Error \\
\hline Male & $0.007^{* * *}$ & $(0.001)$ \\
\hline Age $20-24$ & $0.001^{* * *}$ & $(0.000)$ \\
\hline Age $25-34$ & $0.005^{* * *}$ & $(0.001)$ \\
\hline Age $35-44$ & $0.004 * * *$ & $(0.001)$ \\
\hline Age $45-54$ & $0.003^{* * *}$ & $(0.001)$ \\
\hline Age $55+$ & $0.002^{* * *}$ & $(0.001)$ \\
\hline Leaving Certificate & 0.000 & $(0.001)$ \\
\hline Post Leaving Certificate & $0.001^{* * *}$ & $(0.000)$ \\
\hline Third Level: non degree & $-0.001 * * *$ & $(0.000)$ \\
\hline Third level: degree & $-0.003^{* * *}$ & $(0.001)$ \\
\hline Irish & $-0.013^{* * *}$ & $(0.002)$ \\
\hline Married & 0.000 & $(0.001)$ \\
\hline Border & 0.000 & $(0.000)$ \\
\hline Mid-East & $0.002^{* * *}$ & $(0.000)$ \\
\hline Midlands & $0.001^{* * *}$ & $(0.000)$ \\
\hline Mid-West & $0.001 * * *$ & $(0.000)$ \\
\hline South-East & $0.002 * * *$ & $(0.000)$ \\
\hline South-West & $0.002^{* * *}$ & $(0.000)$ \\
\hline West & $0.002 * * *$ & $(0.000)$ \\
\hline Prev. sector: Agriculture & 0.000 & $(0.000)$ \\
\hline Prev. sector: Construction & 0.000 & $(0.000)$ \\
\hline Prev. sector: Wholesale and retail & 0.000 & $(0.000)$ \\
\hline Prev. sector: Transport and storage & 0.000 & $(0.000)$ \\
\hline Prev. sector: Accommodation and food service activities & $-0.001 * * *$ & $(0.000)$ \\
\hline Prev. sector: Information and communication & $0.000 * * *$ & $(0.000)$ \\
\hline Prev. sector: Financial, insurance and real estate activities & 0.000 & $(0.000)$ \\
\hline Prev. sector: Professional, scientific and technical activities & $0.000^{*}$ & $(0.000)$ \\
\hline Prev. sector: Administrative and support service activities & 0.000 & $(0.000)$ \\
\hline Prev. sector: Public Admin. And defence & 0.000 & $(0.000)$ \\
\hline Prev. sector: Education & 0.000 & $(0.000)$ \\
\hline Prev. sector: Health & 0.000 & $(0.000)$ \\
\hline Prev. sector: Other & 0.000 & $(0.000)$ \\
\hline Prev. sector: No sector info & 0.000 & $(0.000)$ \\
\hline Prev. Permanent Contract & -0.001 & $(0.001)$ \\
\hline Prev. Full-Time & $-0.003 * * *$ & $(0.001)$ \\
\hline Prev. Trade Union Member & 0.000 & $(0.001)$ \\
\hline Prev. Firm Size 11-19 & 0.000 & $(0.000)$ \\
\hline Prev. Firm Size 20-49 & 0.000 & $(0.000)$ \\
\hline Prev. Firm Size 50-99 & 0.000 & $(0.000)$ \\
\hline Prev. Firm Size 100-500 & 0.000 & $(0.000)$ \\
\hline Prev. Firm Size 500+ & 0.000 & $(0.000)$ \\
\hline Constant & $0.022 * * *$ & $(0.004)$ \\
\hline
\end{tabular}


